Historic, Archive Document

Do not assume content reflects current scientific knowledge, policies, or practices. 

Eastman's Seed Specialties 


\section{LIGMTNNO BEAN}

This grand variety of bush bean was introduced by us as the quickest bean on record from planting to the table, a reputation it has maintained for over twenty years. Lovers of green beaıs, either string or shelled, can hasten the season by planting the Lightuing. Only a few days from blossoming the pods are ready for the table, very tender and rich flavored. But they keep right on growing, and in a few days nore the pods have toughened, and are soon fit for shelling. I'lanterl side by side with other varieties. tlie Lightning is invariably first to come into bearng.

By mail postpaid, per quart 50 cts.; punt 30 cis.; pkt. Io cts.

\section{EASTMAN'S EAREY SWEET CORN}

Of all the new varieties of regretables first introfuced into general cultivation by. me. Eastman's Early siveet Corn has had the widest popularity. No other hind

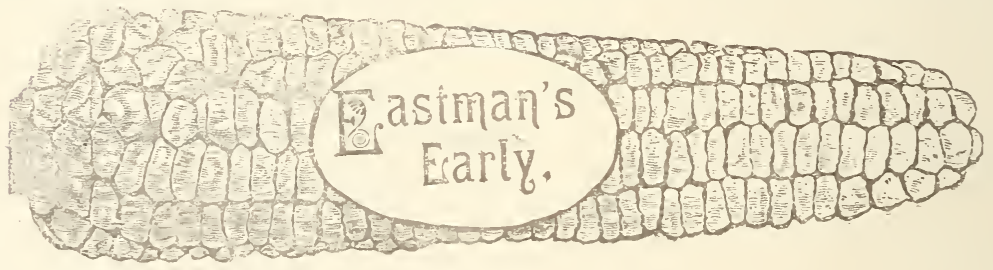

of siveet corn gives the com matien of gond puints found in this variety.

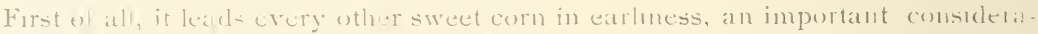
tion for those who wish to hasien th: family sisply or contrebl the eariy matiet.

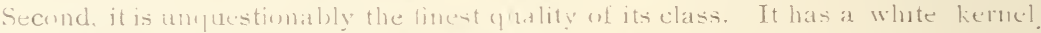

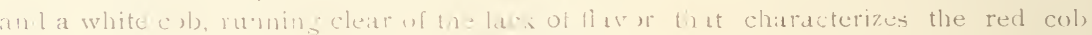
class, and dpporoching m invetness the best later varicties.

Third. it outy ieles all other exth early varictics, thus comblining the three most desirable characteristico of a first early sweet corn.

liy mail postpaid, per quart 50 c's.; pint 30 cts. : pht. Io cts.

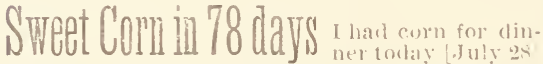
from your seed planted M.1y 11. This heats my jrerious reesert, and my neighbor's ate a little in donbt, althengli some of them saw me pick the
corn.

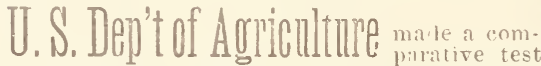
of numerous rarietes at its Fxperint mt Stations

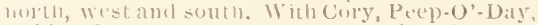
Golden IBantam and other extrat earlies in com-

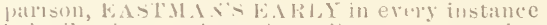
fed all wher rarielles in earliness of maluring the cropt

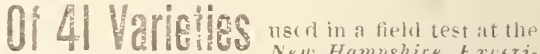
Now Hampshire Ixpitriment station, EISTWIN- EARLY tork the leant in the combination of earliness, riels! and quality.

Rey, J. R. LaWience the well hanwn

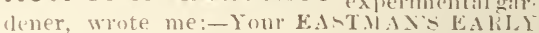
is the eariirst sweet curn, lealing l'tep-(y' lay the last Iwo yeas by a weeh or mole. It is a suept com, also a heary erompre thre to fire eals on many slalk-every year. I had everything kuown in the sweet eorn line for trial, but nothmg prored ar carly as yuurs. 


\section{W. H, EASTMAN, East Sumner, Me.:-}

Please send the following Seeds, etc., to my address, as below.

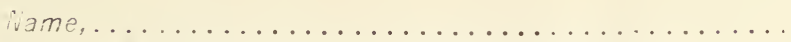

Write name and address distinctly to avoid errors.]

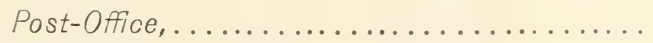

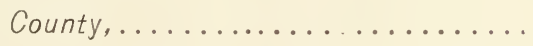

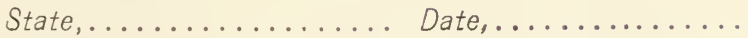

\begin{tabular}{l|l|l}
\hline Quantity. & Name of seed Wanted. \\
Lastman's Early sweet Corn \\
Eastman's Ideal Sweet Corn \\
Eurity Cucumber \\
Granite State Nuskmelon
\end{tabular} \mid




\section{EASTMAN'S IDEAL SWEET CORM}

In the IDEAL we have a sweet corn ready for the table just after Eastman's Early has passed its prime, and surpassing it in every point except earliness. It is



a vigorous grower and a prolific yielder, several good twelve to sixteen rowed ears $t$, the stalk being common, and of superlative sweetness. A fine man crop variety.

By mail postpaid. per quart 60 cts ; pint 35 cts.: half-pint $20 \mathrm{cts}$; pkt. ro cts.

\section{PURITY CUCUMBER}

This pure white cucumber, often attaining a length of two feet and upwards, is p:e eminently an exhbition variety, and everywhere attracts attention. In its earl. stage it is unsurpassed for the table, crisp, tender, of the mildest flavor, which we have never known to be tainted by the slightest hint of bitterness. No other variety equals it for ripe cucumber pickles. We advise planting some earlier cucumber for main crop.

Per oz. 50 cts.; pkt. Io cts. 


\section{GRANITE STATE MUSKMELON}

This earliest of all muskmelons makes successful melon growing posibibie in the most northern of the New Erigland states. The fruit is large (we have raised speci-

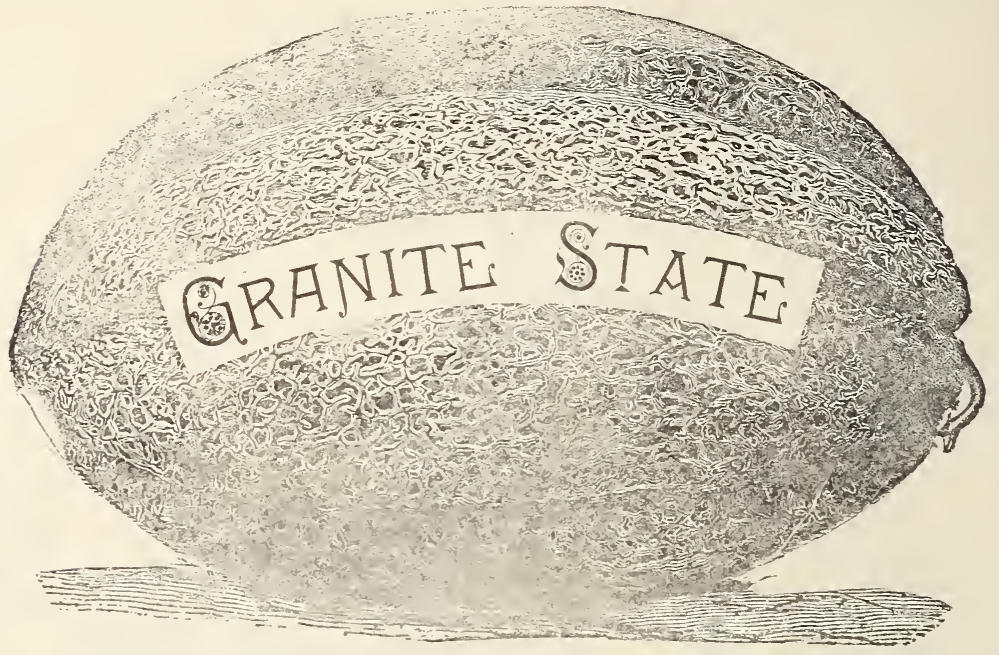

mens weighing seven pounds), oblong. deeply ribbed, greenish yellow when ripe, while the flesh is vry thick, m.sting and richly flavored. Cut in wide sliccs, lightly sprinkled with sugar and eaten with a spoon, it is simply delicious,

Per oz. 5o cts.; pkt. Io cts.

\section{Bulletin 52 xew Hampshive Experiment of 7 rarieties of muskmelons tested. The GRANITE STATE led all others by Eeven days in earliness, and was equaled in yield by two vari- eties only.}

\section{Any three $10 \mathrm{c}$. packets for $25 \mathrm{c}$. The five for $40 \mathrm{c}$.}

If y'ou receive two of these Seed Specialties circulars, kindly pass one along to some one who would he interested. 